\title{
ROLA GIEŁD ENERGII W PROCESIE BUDOWANIA JEDNOLITEGO UNIJNEGO RYNKU DNIA BIEŻĄCEGO I RYNKU DNIA NASTEPPNEGO ENERGII ELEKTRYCZNEJ
}

\begin{abstract}
Celem artykułu jest analiza pozycji giełd energii na rynku energii elektrycznej Unii Europejskiej, która wynika z projektu rozporządzenia Komisji Europejskiej ustanawiającego wytyczne dotyczące alokowania zdolności przesyłowych i zarządzania ograniczeniami. Ten kodeks sieci określa reżim prawny funkcjonowania giełd energii na połączonym Rynku Dnia Bieżącego (RDB) i Rynku Dnia Następnego (RDN) w obrocie pomiędzy strefami cenowymi Unii Europejskiej. Kodeks wskazuje zarówno proponowany model obrotu hurtowego na tych giełdach, jak i ramy instytucjonalne ich funkcjonowania.

Historycznie giełdy energii tworzone były jako element systemu liberalizacji krajowych rynków energii. Ich celem było zbudowanie ram instytucjonalnych zapewniających transparentne warunki transakcji, wyznaczających wiarygodną cenę referencyjną energii elektrycznej oraz udostępniających w niedyskryminujący i przejrzysty sposób informacje rynkowe. Obecnie stanowią one platformy obrotu, często o dużym poziomie płynności, które działają w dwóch obszarach: rynku krajowego i wymiany transgranicznej. Docelowo mają one służyć budowie wewnętrznego rynku energii UE, silnie opartego na zintegrowanym wewnętrznie rynku hurtowym.

Celem tego artykułu jest wskazanie proponowanych w nowym kodeksie sieci rozwiązań w zakresie funkcjonowania giełd energii na RDB i RDN w obrocie między strefami cenowymi Unii Europejskiej.

Słowa kluczowe: giełda energii, NEMO, liberalizacja, rynek energii elektrycznej Unii Europejskiej, kodeks sieci, CACM, rynek hurtowy.
\end{abstract}

\section{WPROWADZENIE}

Zgodnie z planami Unii Europejskiej (UE) wewnętrzny rynek energii elektrycznej miał zacząć funkcjonować od 2014 r. ${ }^{2}$. Jego struktura miała być oparta na regulacjach trzeciego pakietu liberalizacyjnego rynków energii elektrycznej i gazu ziemnego ${ }^{3}$ oraz na

1Dr Robert Zajdler, Wydzial Administracji i Nauk Społecznych, Politechnika Warszawska, radca prawny - kancelaria prawna Zajdler Energy Lawyers, e-mail: info@ zajdler.eu

${ }^{2}$ Konkluzje Rady Europejskiej z 4 lutego 2011 r.; Communication from the Commission:

Delivering the internal electricity market and making the most of public intervention, Brussels,

5.11.2013, C(2013) 7243 final, s. 2-4.

3 Dyrektywa 2009/72/WE Parlamentu Europejskiego i Rady z 13 lipca 2009 r., dotycząca wspólnych zasad rynku wewnętrznego energii elektrycznej i uchylająca dyrektywę 2003/54/WE (DzU UE L 221 z 14.08.2009, s. 55); Dyrektywa Parlamentu Europejskiego i Rady 2009/73/WE z 13 lipca 2009 r., dotycząca wspólnych zasad rynku wewnętrznego gazu ziemnego i uchylająca dyrektywę 2003/55/WE (DzU UE L 211 z 14.08.2009, s. 94-136); Rozporządzenie (WE) nr 714/2009 z 13 lipca 2009 r., w sprawie warunków dostępu do sieci w odniesieniu do transgranicznej 
rozwiązaniach technicznych ujednolicających różne elementy tego rynku, w tym tak zwanych kodeksach sieci ${ }^{4}$. Kodeksy sieci są regulacjami normującymi techniczne aspekty funkcjonowania rynku energii elektrycznej i gazu ziemnego, których projekty wypracowywane są przez samych uczestników rynku, a następnie przyjmowane w drodze komitologii jako akty prawa $\mathrm{UE}^{5}$. Przyjęte $\mathrm{w}$ tych regulacjach rozwiązania stopniowej integracji rynków krajowych, poprzez rozwiązania regionalne, do pełnej unifikacji na poziomie unijnym powoli realizują zakładane cele, jednakże wiele kwestii wciąż nie jest rozwiązanych ${ }^{6}$. Powoduje to, że zakładana pierwotnie data utworzenia wewnętrznego rynku energii elektrycznej UE przesunie się o kilka lat. Jednak zachodzące procesy dają ważny asumpt do rozważań na temat pożądanych kierunków tych zmian, w tym tych dotyczących kształtu rynku hurtowego energii elektrycznej.

$\mathrm{W}$ procesie budowania rynku hurtowego energii elektrycznej coraz bardziej znaczącą rolę zaczynają odgrywać giełdy energii. Początkowo te platformy obrotu hurtowego tworzone były jako instytucjonalny element systemu liberalizacji krajowych rynków energii. Ich celem było zbudowanie ram instytucjonalnych zapewniających transparentne warunki transakcji, wyznaczających wiarygodną cenę referencyjną oraz udostępniających w niedyskryminujący i przejrzysty sposób informacje rynkowe. Ich regulacja opierała się w dużej mierze na przepisach prawa krajowego. Obecnie znaczenie giełd energii znacznie wykracza poza te cele. Na części rynków krajowych stanowią one platformy obrotu o dużym poziomie płynności, które działają w dwóch obszarach: rynku krajowego i wymiany transgranicznej. Ze względu na uwarunkowania rynku energii elektrycznej istnieje wciąż wyraźny podział na oba te obszary obrotu. Wynika to $\mathrm{w}$ dużej mierze $\mathrm{z}$ dużej autonomii każdego z rynków krajowych, stanowiących odrębne obszary regulacji i obrotu. Wymiana transgraniczna stanowi w dużej mierze uzupełnienie rynku krajowego. Ta sytuacja ulega jednak zmianie. Integracja prawna i infrastrukturalna między państwami członkowskimi UE sprawia, że innego znaczenia zaczyna nabierać wymiana transgraniczna, integrując się coraz bardziej z rynkiem krajowym. Zaproponowane rozwiązania w zakresie stref cenowych sprawiają, że handel energią elektryczną na rynku hurtowym między państwami członkowskimi będącymi w ramach jednej strefy cenowej jest tożsamy $\mathrm{z}$ handlem $\mathrm{w}$ ramach tego państwa członkowskiego UE. Dodatkowo stopniowa integracja krajowych giełd energii w regionalne platformy obrotu umacnia ten proces. Oferują one poza obrotem towarowym również wiele dodatkowych produktów dla uczestników rynku, w tym zbudowany w oparciu na tych giełdach rynek finansowy.

wymiany energii elektrycznej i uchylające rozporządzenie (WE) nr 1228/2003 (DzU UE L 211 z 14.08.2009, s. 15); Rozporządzenie (WE) nr 715/2009 Parlamentu Europejskiego i Rady z 13 lipca 2009 r., w sprawie warunków dostępu do sieci przesyłowych gazu ziemnego i uchylające rozporządzenie (WE) nr 1775/2005 (DzU UE L 211, 14.08.2009, s. 36-54); Rozporządzenie (WE) nr 713/2009 Parlamentu Europejskiego i Rady z 13 lipca 2009 r., ustanawiające Agencję ds. Współpracy Organów Regulacji Energetyki (DzU UE L 211, 14.08.2009, s. 1).

${ }^{4}$ Szerzej: http://networkcodes.entsoe.eu.

${ }^{5}$ Zob. szerzej: A Walaszek-Pyzioł, Kilka refleksji na temat europejskich kodeksów sieci (grid codes) [w:] A. Walaszek-Pyzioł (red.), Regulacja - innowacja w sektorze energetycznym, Warszawa 2013, s. 171-179.

${ }^{6}$ European Energy Regulation, A Bridge to 2025, Public Consultation Paper, PC_2014_O_01, 29

April 2014, s. 5-15. 
Proces integracji tych platform obrotu wciąż trwa i jest dodatkowo wspierany regulacjami prawa Unii Europejskiej w zakresie transparentności i przejrzystości rynku hurtowego.

Celem tego artykułu jest wskazanie proponowanych w nowym kodeksie sieci rozwiązań w zakresie funkcjonowania giełd energii na Rynku Dnia Bieżącego (RDB) i Rynku Dnia Następnego (RDN) w obrocie pomiędzy strefami cenowymi UE. Wskazane będzie miejsce giełd w ramach struktury rynku energii elektrycznej oraz ich kompetencje. Wskazano również na kwestie wymagające dalszej, bardziej szczegółowej regulacji.

\section{PODSTAWY PRAWNE REGULACJI}

Regulacja prawna określająca zasady funkcjonowania giełd energii na RDB i RDN zawarta jest w przedstawionym przez Komisję Europejską w sierpniu 2014 r. kodeksie sieci, czyli projekcie rozporządzenia Komisji Europejskiej ustanawiającym wytyczne dotyczące alokowania zdolności przesyłowych i zarządzania ograniczeniami (Capacity Allocation and Congestion Management - CACM lub Kodeks) ${ }^{7}$.

Prace nad tym aktem prawnym rozpoczęły się w styczniu 2011 r., gdy Komisja Europejska zwróciła się z wnioskiem do Agency for Cooperation of Energy Regulators ACER o przygotowanie Wytycznych Ramowych, które zostały przez ACER opublikowane 29 lipca 2011 r. Kolejnym etapem był wniosek z 23 marca 2012 r. o rozpoczęcie prac nad Kodeksem przez operatorów systemów przesyłowych zrzeszonych w ENTSO-E (European Network of Transmission System Operators for Electricity), przy udziale uczestników rynku. Ostateczna wersja projektu została przesłana pod koniec 2013 r. do Komisji Europejskiej w celu rozpoczęcia oficjalnej procedury przyjęcia tego dokumentu jako rozporządzenia UE. Uzgodniony w ramach tak zwanej komitologii ${ }^{8}$ wniosek został zaprezentowany w sierpniu 2014 r. Wejście Kodeksu w życie jest wstępnie planowane na początek $2015 \mathrm{r}$.

Równocześnie z pracami nad tym dokumentem zaproponowano podjęcie działań w niektórych obszarach objętych Kodeksem przez uczestników rynku w celu zdiagnozowania kluczowych problemów i wypracowania mechanizmów służących efektywnemu wdrożeniu jego rozwiązań po jego oficjalnym wejściu w życie (early implementation). Działania te objęły: rewizję obecnego kształtu stref cenowych, wdrażanie alokacji na podstawie metody FBA, wdrażanie wspólnych zasad świadczenia usług przekierowania i wymiany kompensacyjnej, zasad łączenia rynków RDB i RDN oraz metodologii tworzenia algorytmów łączenia cen ${ }^{9}$.

\footnotetext{
${ }^{7}$ Dostęp do dokumentu jest możliwy poprzez tzw. Rejestr Dokumentów Procedury Komitetowej (Comitology Register) dostępny pod adresem internetowym: http://ec.europa.eu/transparency/regcomitology/index.cfm?do=Search.Search\&NewSearch=1 .

8 Powyższe rozporządzenie jest przyjmowane $w$ ramach procedury regulacyjnej połączonej $\mathrm{z}$ kontrolą, zgodnie z art. 5a decyzji Rady 1999/468/WE z dnia 28 czerwca 1999 r. ustanawiajacej warunki wykonywania uprawnień wykonawczych przyznanych Komisji (częściowo pozostającej w mocy - w zakresie procedury PRAC/RPS) oraz zastępującym ww. decyzję rozporządzeniu Parlamentu Europejskiego i Rady (UE) nr 182/2011 z dnia 16 lutego 2011 r. ustanawiajacym przepisy $i$ zasady ogólne dotyczace trybu kontroli przez państwa członkowskie wykonywania uprawnień wykonawczych przez Komisję.

${ }^{9}$ Szerzej: http://ec.europa.eu/energy/gas_electricity/electricity/forum_electricity_florence_en.htm.
} 


\section{CELE REGULACJI KODEKSU}

Celem wydania Kodeksu jest uregulowanie w niedyskryminujący sposób zasad alokacji zdolności przesyłowych na połączeniach transgranicznych pomiędzy strefami cenowymi i zasad zarządzania ograniczeniami w zakresie RDB i RDN. Stefa cenowa (bidding zone) to ograniczona geograficznie część sieci, w której składane są zlecenia kupna i sprzedaży energii elektrycznej i możliwe jest wyznaczenie jednolitej ceny rynkowej energii dla określonej godziny lub grupy godzin na obu rynkach, bez konieczności uwzględniania ograniczeń dostępnej zdolności przesyłowej. Obecnie większość państw członkowskich UE stanowi jedną strefę cenową. Kodeks zakłada jednak łączenie sąsiadujących państw członkowskich w jedną strefę cenową, co oznacza, że zasady wyznaczania zdolności przesyłowej oraz zasady obrotu energią elektryczną na tak połączonych obszarach będą się zbliżały coraz bardziej do tego, jak wygląda to w ramach danego państwa. Kodeks nie przesądził ostatecznego kształtu takich stref cenowych, tworząc jednak jasne kryteria określające metodologię ich powstania.

Konfiguracja stref cenowych ma znaczenie dla rozwoju rynku hurtowego, inwestycji w wytwarzanie, ujednolicania cen pomiędzy strefami cenowymi i kosztów bilansowania. Pierwotnie podział na strefy cenowe zaproponowano w rozporządzeniu 714/2009 z 13 lipca 2009 r. w sprawie warunków dostępu do sieci w odniesieniu do transgranicznej wymiany energii elektrycznej i uchylające rozporządzenie (WE) nr 1228/2003 ${ }^{10}$. Podział ten zakładał istnienie kilku dużych stref cenowych: Europa Północna (Dania, Szwecja, Finlandia, Niemcy i Polska), Europa Północno-Zachodnia (Beneluks, Niemcy i Francja), Włochy (Włochy, Francja, Niemcy, Austria, Słowenia i Grecja), Europa ŚrodkowoWschodnia (Niemcy, Polska, Republika Czeska, Słowacja, Węgry, Austria i Słowenia), Europa Południowo-Zachodnia (Hiszpania, Portugalia i Francja), Zjednoczone Królestwo, Irlandia i Francja, Państwa Bałtyckie (Estonia, Łotwa i Litwa). Prowadzone w ramach tak zwanych wczesnych implementacji Kodeksu prace nad kształtem stref cenowych zakładają różne scenariusze, w tym możliwość połączenia niektórych stref w większe (merging) oraz podziału innych na mniejsze (splitting). W ramach tego drugiego kierunku stworzono również projekt podziału Polski na dwie strefy cenowe. Abstrahując od ceny sprzedaży energii elektrycznej, możliwość oferowania energii elektrycznej na rynku hurtowym na większym obszarze, bez konieczności uwzględniania ryzyka dostępności połączeń między strefami cenowymi wydaje się bardziej korzystne, zarówno dla wytwarzania, jak i dla obrotu hurtowego, gdyż zapewnia łatwiejsze uplasowanie wytworzonej energii oraz ogranicza ryzyko rentowności inwestycji w moce wytwórcze. Większe strefy cenowe powinny zapewnić również łatwiejsze bilansowanie źródeł stabilnych i mniej stabilnych w ramach jednego obszaru. Zmiana taka wymagać będzie jednak większej współpracy między operatorami systemów przesyłowych połączonych obszarów ${ }^{11}$.

\footnotetext{
${ }^{10}$ Dz. Urz. UE L 211 z 14.08.2009, s. 15.

${ }^{11}$ Szerzej: ENTSO-E Bidding Zone Task Force 21.05.2014, Analytical Framework for Bidding Zone Configurations; ENTSO-E Market Integration Working Group, Terms of Reference for the early implementation of the NC CACM concerning a Bidding Zone Review in CWE (Belgium, France, Germany, Luxembourg, the Netherlands), Denmark-West, CEE (Austria, Czech Republic, Germany, Hungary, Poland, Slovenia, Slovakia, Switzerland); and Italy, October 2012; ACER, The influence of existing bidding zones on electricity markets, Consultation document, PC_2013_E_04
} 
Ostateczny kształt stref cenowych będzie jednak przedmiotem dalszych prac i uzgodnień. Z tym jednak wiąże się sposób wyznaczania przez operatorów systemów przesyłowych dostępnych na cele handlowe zdolności przesyłowych pomiędzy strefami cenowymi. Kodeks promuje jednolitą metodę wyznaczania zdolności przesyłowej, opartą na tak zwanych fizycznych przepływach (FBA, Flow Based Allocation) dla strefy cenowej oraz jednolity model transakcji opartych na zasadach alokacji implicit, czyli łącznej sprzedaży zdolności przesyłowej i energii elektrycznej. Wprowadza tym samym nowy ujednolicony model rynku oparty na metodologii oraz enumeratywnie określonych funkcjach, przypisanych odpowiednim jednostkom, w tym również giełdom energii, na których w ramach jednego instrumentu obracana będzie energia elektryczna i zdolność przesyłowa niezbędna do dostarczenia tej energii pomiędzy strefami cenowymi. Kodeks wprowadza rozbudowane zasady kontroli i raportowania do instytucji publicznych (Komisja Europejska, ACER, krajowe organy regulacyjne).

\section{NEMO JAKO FUNKCJA GIEŁDY ENERGII}

Kodeks kształtuje nowy model obrotu hurtowego, w którego ramach szczególną rolę odgrywa giełda energii ${ }^{12}$. Kodeks przypisuje wskazanym do pełnienia funkcji w zakresie obrotu na RDN i RDB giełdom energii określone funkcje. Zasadnicze z nich to pełnienie funkcji Nominated Electricity Market Operator (NEMO) oraz Market Coupling Operator (MCO). Operator NEMO jest operatorem rynku, wyznaczonym przez właściwy organ do prowadzenia obrotu w ramach jednego wspólnego RDN i RDB. Zadaniem MCO jest łączenie zleceń dla wszystkich stref cenowych w ramach RDN i RDB, biorąc pod uwage dostępną na cele handlowe zdolność przesyłową oraz istniejące ograniczenia przesyłowe.

Zgodnie $\mathrm{z}$ art. 4 CACM każde państwo członkowskie wyznacza co najmniej jednego NEMO na 4 lata do prowadzenia obrotu na RDN i RDB. Każdy wniosek o pełnienie funkcji NEMO powinien być potraktowany przez państwo członkowskie w niedyskryminujący sposób. Oznacza to brak wskazania w projektowanych regulacjach, które $\mathrm{z}$ istniejących na danych rynkach giełdy energii mają być wyznaczone do pełnienia tej funkcji, dając możliwość ubiegania się o tę funkcje każdemu zainteresowanemu podmiotowi spełniającemu określone w art. 6 CACM wymagania formalne: 1) posiadanie odpowiednich zasobów operacyjnych (kadrowych, finansowych, organizacyjnych); 2) zapewnienie równego, otwartego dostępu do istotnych informacji uczestnikom rynku; 3) zapewnienie efektywności kosztowej działania; 4) zapewnienie niezależności od innych uczestników rynku; 5) zagwarantowanie niedyskryminacyjnego traktowania uczestnikom rynku; 6) podleganie pod właściwy nadzór rynkowy; 7) uregulowany umownie obowiązek zachowania poufności i przejrzystości z uczestnikami rynku i operatorami systemów przesyłowych; 8) zapewnienie niezbędnych usług rozliczeniowo-rozrachunkowych. Kryteria te mają zapewnić, że konkurencja między NEMO jest oparta na uczciwych i niedyskryminujących kryteriach.

Dodatkowo Kodeks zapewnia możliwość transgranicznego świadczenia usług NEMO. Oznacza to, że giełda energii z jednego państwa członkowskiego i desygnowana w tym państwie do pełnienia funkcji NEMO może świadczyć tego rodzaju funkcje również w

31, July 2013; ENTSO-E, Bidding Zones Review, $1^{\text {st }}$ stakeholder advisory group, Brussels, 27 June 2014.

${ }^{12}$ Zob. Elforsk, The Increasing Scope and Authority for Power Exchanges, Elforsk rapport 13:57, June 2013. 
innym państwie bez dodatkowych wymagań. Kodeks zabrania dyskryminacji w tym zakresie - ma to służyć zapewnieniu konkurencji między NEMO i budowaniu wewnętrznego rynku energii UE opartego na rynkowej wycenie również usług świadczonych przez NEMO.

Od tych zasad możliwe są jednak dwa wyjątki. Zgodnie z pierwszym państwo członkowskie może wskazać podmiot, który na jego terytorium będzie pełnił funkcje NEMO. W takim wypadku krajowy organ regulacyjny (w Polsce Prezes URE) określi i zaakceptuje opłaty, jakie będzie pobierał NEMO od uczestników rynku za udział w RDN i RDB. Określi on również metodologię kalkulacji takich opłat. Rozwiązania te ograniczają możliwość konkurowania między NEMO na danym obszarze, dając kompetencje do takiego limitowania władzom danego państwa. Rozwiązanie takie z jednej strony pozwala budować silną pozycję wyznaczonej do pełnienia takiej funkcji giełdy energii, co ma znaczenie na integrującym się geograficznie i produktowo rynku UE. Z drugiej strony ogranicza możliwość zwiększania efektywności działalności tych podmiotów na podstawie mechanizmów rynkowych. Narzędziem do zapewnienia adekwatności opłat pobieranych przez NEMO od uczestników rynku jest krajowy organ regulacyjny, który ustala w tym zakresie stawki opłat i metodologie ich ustalania. Jednak w wypadku braku konkurencji między NEMO porównanie i ustalenie zasadności takich opłat przez organ regulacyjny mogą być utrudnione.

Zgodnie z drugim wyjątkiem możliwe jest ograniczenie transgranicznego świadczenia usług przez NEMO z innego państwa członkowskiego (obszaru cenowego) na terytorium danego państwa na podstawie decyzji danego państwa członkowskiego. Podstawą takiego ograniczenia może być niekompatybilność świadczonych transgranicznie usług albo zasad ich świadczenia z tymi na terenie danego państwa. Może ono również mieć wyłącznie charakter czasowy, czyli do usunięcia uzasadnionych niekompatybilności wewnętrznych zasad obrotu tego państwa z zasadami o charakterze transgranicznym. Zastosowanie tego ograniczenia podlega kontroli między innymi Komisji Europejskiej i ACER, a jego zastosowanie wymaga opinii krajowego organu regulacyjnego.

Wprowadzenie NEMO zapewni większą przejrzystość i kontrolę rezerwacji zdolności przesyłowych pomiędzy strefami cenowymi w ramach RDN i RDB. Integracja platform obrotu hurtowego w ramach UE, niezależnie od tego, czy za pomocą wyznaczania jednego NEMO dla więcej niż jednego obszaru regulacji, czy też utrzymania odrębnych, ale współpracujących ze sobą NEMO z poszczególnych obszarów regulacji, może powodować zmniejszenie kosztów udziału w rynku hurtowym ze względu na wprowadzone mechanizmy kontroli kosztów oraz otwarcie każdego NEMO na konkurencję ze strony innych NEMO. Możliwość transgranicznego działania NEMO może ułatwiać uczestnikom rynku udział w obu rynkach. Możliwość istnienia monopolu krajowego w zakresie usług jednego NEMO lub braku możliwości transgranicznego świadczenia usług może rodzić dodatkowe koszty działalności na rynku hurtowym. W wypadku podjęcia takiej decyzji przez władze Polski, konieczne będzie dążenie do rynkowej wyceny opłat za usługi świadczone przez krajowe NEMO. Z kolei brak wystarczającego nadzoru regulacyjnego nad NEMO przy dążeniu giełd energii do ich unifikacji w skali UE może wpływać na ograniczoną konkurencję między nimi, a to może mieć znaczenie dla uczestników rynku, zwłaszcza w sytuacji wyznaczania jednego NEMO dla więcej niż jednego obszaru regulacji. Integracja hurtowych platform obrotu będzie wymagać większego zaangażowania regulacyjnego. Konieczne wydaje się stworzenie ram prawnych dla zapewnienia właściwej kontroli nad działalnością NEMO 
oraz nad zasadnością ewentualnego ograniczania transgranicznego działania NEMO przez państwa członkowskie.

\section{MIEJSCE NEMO W ARCHITEKTURZE RYNKU DNIA BIEŻĄCEGO I RYNKU DNIA NASTĘPNEGO}

Kodeks wprowadza ujednolicone uregulowania w zakresie funkcjonowania RDN i $\mathrm{RDB}$, przewidując określone zadania i kompetencje dla giełd energii, w tym przede wszystkim dla NEMO. Zgodnie z zapisami Kodeksu w ramach wymiany transgranicznej pomiędzy strefami cenowymi uczestnicy rynku giełdowego składają zlecenia kupna lub sprzedaży energii elektrycznej do operatora rynku, czyli podmiotu, którego zadaniem jest prowadzenie obrotu na RDB i RDN, to jest NEMO. W danej strefie cenowej może występować jeden lub więcej NEMO, w zależności od decyzji właściwych władz. Dla przykładu w Polsce, która jest obecnie jednym obszarem rynkowym, rolę taką odgrywać może Towarowa Giełda Energii S.A. (TGE), ale możliwe jest również wskazanie przez właściwe władze innego podmiotu oprócz TGE lub zamiast niej, bądź umożliwienie funkcjonowania transgranicznie podmiotu $\mathrm{z}$ innego państwa.

Pozycja NEMO w strukturze administracyjnej na RDB i RDN jest zbliżona. Na RDN, zgodnie z podstawową procedurą składania zleceń przez uczestników rynku, do godziny 11.00 dnia poprzedzającego (dzień D-1) operatorzy systemu przesyłowego przekazują dane o dostępnej handlowo zdolności przesyłowej do NEMO. Następnie pomiędzy godziną 11.00 a 12.00 dnia D-1 odbywa się aukcja administrowana przez NEMO. Zasadą jest aukcja w trybie implicit, czyli jednoczesna sprzedaż energii elektrycznej i zdolności przesyłowej połączenia wzajemnego niezbędnej do realizacji tej transakcji ${ }^{13}$. Wyniki aukcji przekazywane są przez właściwe NEMO do operatora połączonego rynku, czyli MCO, który ustala cenę rozliczeniową dla każdej godziny handlu, bilans handlu oraz stan wykonania zleceń. Rozliczenia te przekazywane są następnie do NEMO i operatorów systemów przesyłowych w celu realizacji zleceń oraz ich rozliczeń i rozrachunku. Taki model rynku ma na celu zapewnienie większej efektywności jego funkcjonowania. Ujednolicone zasady prowadzenia obrotu utrudniają arbitraż między poszczególnymi połączeniami wzajemnymi, ponieważ mechanizm alokacji i zakres posiadanej przez uczestników rynku informacji rynkowej są takie same. Dla RDB określono również jednolity model obrotu. Informacje o zdolnościach i ograniczeniach przesyłowych będa dostarczane przez operatora systemu przesyłowego do NEMO nie później niż 15 minut przed otwarciem rynku. NEMO publikują te informacje bez nieuzasadnionej zwłoki, umożliwiając uczestnikom rynku określenie swoich strategii handlowych. Następnie NEMO dostarczają te informacje do algorytmu, który w sposób ciągły łączy składane przez uczestników rynku oferty. Na tej podstawie dokonuje się przydziału zdolności oraz rozliczenia i rozrachunku transakcji.

NEMO mają działać jako operatorzy na krajowym lub regionalnym RDN i RDB. Ich zadania obejmować będą: przyjmowanie zleceń od uczestników rynku, łączenie zleceń uczestników rynku i alokowanie ich zgodnie z wynikami jednego połączonego RDN i RDB, publikowanie cen oraz rozrachunek i rozliczenie zawartych umów zgodnie z właściwymi umowami i uregulowaniami. $\mathrm{W}$ ramach tych zadań NEMO powinny

\footnotetext{
${ }^{13}$ Kodeks przewiduje możliwość czasowego stosowania aukcji explicit na określonych zasadach, docelowo jednak zakłada się jednolite alokowanie na podstawie aukcji implicit.
} 
zapewniać: wdrożenie i koordynowanie z innymi NEMO funkcji MCO, wypracowanie wspólnie wymagań dla jednego połączonego RDN i RDB oraz wymagań dla funkcji MCO i algorytm łączenia cen, ustalanie cen maksymalnych i minimalnych, zapewnienie anonimowości i udostępnianie informacji o zleceniach $\mathrm{w}$ ramach funkcji MCO, ocenę wyników wyliczonych przez MCO, alokowanie zgodnie z potwierdzonymi wynikami oraz weryfikację, informowanie uczestników rynku o realizacji ich zleceń, rozliczenie i rozrachunek transakcji handlowych pomiędzy strefami cenowymi, wdrażanie procedur awaryjnych na rynku krajowym lub regionalnym, jeśli brak danych wygenerowanych przez MCO, dostarczanie prognoz kosztów jednego połączonego RDN i RDB oraz dostarczanie informacji o kosztach właściwym organom regulacyjnym oraz operatorom systemów przesyłowych, gdy koszty działania NEMO i MCO ponoszone są przez tych operatorów.

$\mathrm{W}$ tej strukturze rynku giełdy energii pełnią centralną funkcję $\mathrm{w}$ zakresie administrowania obrotem. Do nich dostarczane są istotne informacje rynkowe oraz za ich pośrednictwem następuje proces skutkujący realizacją zleceń. Ogranicza to rolę operatorów systemów przesyłowych do kwestii zapewnienia technicznej możliwości realizacji transakcji, przenosząc na giełdy energii kwestie związane z handlem. Regulacja ta określa zadania NEMO, zwracając szczególną uwagę na reguły konkurencji i nienadużywanie pozycji dominującej lub monopolistycznej przez te podmioty. Ich rolą będzie zbudowanie głównych zasad obrotu opartych o jednolicie określone procedury, algorytmy i zasady obrotu.

\section{GŁÓWNE ELEMENTY NOWEGO MODELU TWORZONE PRZEZ NEMO}

Giełdy energii przez NEMO mają udział w ujednolicaniu wewnętrznego rynku energii elektrycznej UE. Kodeks wprowadza kilka technicznych ujednoliceń: wspólny algorytm łączenia cen, zharmonizowaną cenę maksymalną i minimalną, zasady wyceny zdolności przesyłowej, czy też ujednolicone zasady oferowania nowych instrumentów. NEMO odpowiedzialne są za stworzenie tych ram działania rynku oraz ich bieżące administrowanie.

W zakresie algorytmu łączenia cen, zgodnie z art. 35-36 oraz 49-50 CACM, NEMO tworzą wspólnie algorytm połączonej ceny odrębnie dla RDN i RDB i na jego podstawie prowadzą obrót na obu rynkach. Algorytm RDN powinien: dążyć do maksymalizowania nadwyżki rynkowej ${ }^{14}$, wykorzystywać ceny marginalne do wyznaczenia jednej ceny rozliczeniowej dla każdej godziny dla obszaru rynkowego, umożliwiać efektywne kształtowanie się ceny, uwzględniać alokacje zdolności na połączeniach między strefami cenowymi oraz ograniczenia sieciowe. Dla RDB algorytm powinien w sposób ciągły łączyć zlecenia na połączonym rynku oraz uwzględniać: dążenie do maksymalizacji nadwyżki rynkowej dla każdej połączonej oferty kupna-sprzedaży, uwzględniać ograniczenia i dostępne zdolności przesyłowe. Oba algorytmy powinny zapewnić efektywność, niezależnie od skali działania, oraz powtarzalność ich działania. Algorytm dla RDN powinien dostarczyć uczestnikom rynku informację o: jednej cenie

\footnotetext{
${ }^{14}$ Nadwyżka rynkowa - ekonomiczny wskaźnik efektu łączenia rynków definiowany jako suma zysku odbiorców i dostawców wynikająca z udziału w jednym wspólnym rynku. Zysk odbiorców wynika $\mathrm{z}$ obniżki ceny zakupu energii $\mathrm{w}$ stosunku do ceny, jaką byli gotowi zapłacić. Zysk dostawców wynika z wyższej ceny sprzedaży energii w stosunku do ceny, za jaką byli gotowi sprzedać. Do zysku dolicza się również dochody z ograniczeń.
} 
rozliczeniowej dla każdej strefy cenowej rynkowego i każdej godzinie działania RDN wyrażonej w EUR/MWh, bilansie obrotu pomiędzy strefami cenowymi dla każdej godziny działania RDN oraz statusie wykonania zleceń. Dla RDB określać ma co najmniej stan realizacji zleceń i cenę każdego zrealizowanego zlecenia oraz planowaną wymianę energii dla każdej godziny obrotu. Przepisy Kodeksu przewidują zatem pewne minimum informacji w zakresie obrotu udostępniane w sposób jednolity uczestnikom rynku przez giełdy energii. Zapewnić ma to porównywalne warunki handlu dla wszystkich uczestników rynku. Dodatkowo obowiązek zapewnienia przejrzystości i niedyskryminacji ma skutkować brakiem uprzywilejowania niektórych z nich.

Algorytm powinien również umożliwiać tworzenie instrumentów przez NEMO dotyczących więcej niż jednej godziny obrotu. Oprócz tego NEMO powinny zapewniać uczestnikom rynku nowe produkty, jeżeli konsultacje $\mathrm{z}$ nimi potwierdzą konieczność ich wprowadzenia. Ze względu na słabość połączeń wzajemnych (interkonektorów) na części giełd energii (w tym w Polsce) istnieje mało produktów obejmujących wymianę transgraniczną. Wprowadzenie tej możliwości, jeśli założyć większe możliwości handlu pomiędzy strefami cenowymi, spowoduje konieczność dostosowania strategii handlowej i wiedzy do nowych warunków. Istnienie obowiązku współpracy giełd energii z uczestnikami rynku w zakresie nowych produktów skutkuje ciągłą koniecznością rozwoju rynku hurtowego i jego dalszej integracji. Istotne jest jednak właściwe zaplanowanie tego procesu, aby nie doszło do rozproszenia wolumenów obrotu na zbyt dużej ilości instrumentów oferowanych przez konkurujące ze sobą giełdy, a tym samym - do deprecjacji znaczenia ceny referencyjnej generowanej przez te rynki. Może się tak stać w sytuacji nierynkowego oddziaływania na cenę poprzez instrumenty o małym wolumenie obrotu i większej podatności na pozarynkowy wpływ.

Kolejnym ujednolicającym działaniem będzie wprowadzenie przez NEMO, we współpracy $\mathrm{z}$ właściwymi operatorami systemów przesyłowych, zharmonizowanych maksymalnych i minimalnych cen w ofertach składanych na RDN i RDB, które mają być zastosowane we wszystkich strefach cenowych. Ze względu na system alokacji zdolności przesyłowych (aukcje implicit) konieczne będzie branie pod uwagę wyceny zdolności przesyłowej, a zatem istniejących ograniczeń przesyłowych, oraz różnicy w cenie rozliczeniowej pomiędzy właściwymi obszarami rynkowymi. Kodeks zabrania pobierania jakichkolwiek innych opłat $\mathrm{z}$ tym związanych. Oznacza to zatem, że marginesem opłacalności handlu transgranicznego będzie różnica pomiędzy cenami energii na obu rynkach oraz kosztami dostarczenia energii w ramach tych aukcji. Jednolita cena minimalna i maksymalna ma znaczenie dla obrotu hurtowego, gdyż ujednolica sposób kształtowania oraz ceny w obszarze strefy cenowej. Może mieć znaczenie dla zasadności podejmowania arbitrażu cenowego między strefami cenowymi.

\section{ZNACZENIE AUKCJI REGIONALNYCH}

Kodeks przewiduje możliwość utworzenia dodatkowej aukcji regionalnej w ramach RDB. Z wnioskiem takim muszą wystapić właściwe terytorialnie NEMO i operatorzy systemów przesyłowych. Aukcja taka ma mieć komplementarny charakter w stosunku do obrotu w ramach jednolitego wspólnego RDB.

Aukcja może być utworzona w ramach lub pomiędzy strefami cenowymi. W celu zapewnienia skuteczności tej aukcji na czas jej działania zostają zawieszone obroty na RDB na okres niezbędny do obrotu w ramach aukcji regionalnej, ale nie krócej niż na 10 
minut. Pozwoli to na zbilansowanie pozycji na mniejszym obszarze, zanim obrót będzie prowadzony w ramach RDB. Metodologia ustalenia ceny może być inna w ramach aukcji regionalnej, ale powinna uwzględniać ograniczenia przesyłowe oraz aktualne zlecenia uczestników rynku.

Projekt wdrożenia aukcji regionalnej zatwierdzają właściwe organy regulacyjne. Muszą one wziąć pod uwagę między innymi to, czy funkcjonowanie takiej aukcji: 1) nie wpłynie negatywnie na płynność ogólnoeuropejskiego RDB; 2) dotyczyć będzie całej zdolności przesyłowej w danym obszarze; 3) nie będzie dyskryminacji między uczestnikami rynku; 4) ramy czasowe będą zbieżne z jednolitym połączonym RDB, umożliwiając uczestnikom rynku dokonywanie transakcji jak najbliższych czasowi rzeczywistemu.

Przepis wprowadza zatem możliwość dodatkowych aukcji, których znaczenie jest trudne do określenia $\mathrm{w}$ obecnym kształcie. Może to być $\mathrm{z}$ jednej strony dodatkowa platforma obrotu hurtowego ułatwiająca uczestnikom rynku zbilansowanie ich pozycji, ograniczająca przez to znaczenie rynku bilansującego. Istnienie takiej platformy może jednak negatywnie oddziaływać na pozostałe platformy obrotu, zmniejszając wolumeny i ograniczając transparentność i wiarygodność ustalanej na tym rynku ceny referencyjnej. Dla całościowej oceny dodatkowo znaczenie będą mieć: faktyczne możliwości wykorzystania zdolności przesyłowych na cele handlowe udostępniane przez operatorów systemów przesyłowych, sposób prowadzenia obrotu oraz algorytm ustalania ceny.

\section{KOSZTY FUNKCJONOWANIA I KONTROLA NAD NEMO}

Kodeks przewiduje również jasne zasady ponoszenia kosztów funkcjonowania giełd energii w ramach jednolitego wspólnego RDN i RDB. Corocznie NEMO i operatorzy systemów przesyłowych przygotowują raport dla krajowych organów regulacyjnych, w którym przekazują informację o kosztach funkcjonowania obu rynków. Raport jest publikowany przez ACER.

Koszty różnicuje się na: 1) koszty wspólne - wynikające ze skoordynowanych działań NEMO i operatorów systemów przesyłowych w ramach RDN i RDB; 2) koszty regionalne - wynikające $\mathrm{z}$ aktywności NEMO i tych operatorów w danym regionie; 3 ) koszty krajowe - wynikające $\mathrm{z}$ aktywności NEMO i operatorów w danym państwie członkowskim. Wspólne koszty są dzielone między operatorów i NEMO w uczestniczących państwach członkowskich i państwach trzecich. Obliczona kwota, którą ma zapłacić każde państwo, zostanie podzielona następująco: 1/8 wspólnych kosztów równo na każde państwo, 5/8 proporcjonalnie do konsumpcji każdego państwa i 2/8 równo na każdego uczestniczącego NEMO. Kalkulacja kosztów będzie regularnie uaktualniana, aby zapewnić zgodność ze stanem faktycznym. Koszty regionalne będą dzielone między NEMO i operatorów systemów przesyłowych na podstawie wspólnego porozumienia.

\section{PODSUMOWANIE}

Historycznie giełdy energii tworzone były jako instytucjonalny element systemu liberalizacji krajowych rynków energii. Ich celem było zbudowanie ram instytucjonalnych zapewniających transparentne warunki transakcji, wyznaczających wiarygodną cenę rynkową oraz udostepniających w niedyskryminujący i przejrzysty sposób informacje rynkowe. Obecnie stanowią one często platformy obrotu o dużym poziomie płynności, 
które działają w dwóch obszarach: rynku krajowego i wymiany transgranicznej. Docelowo mają być one platformami integrującymi rynek energii Unii Europejskiej.

Nowy model obrotu hurtowego, oparty na instytucji giełdy energii, jest kształtowany przez CACM. Zakłada on stopniową integrację zarówno samych giełd, jak i obszarów ich działania (stref cenowych), budując w ten sposób jednolity model rynku. Szczególną rolę w tym systemie odgrywa NEMO, któremu przydzielono zadania w zakresie zbudowania infrastruktury nowego modelu rynku i jej bieżące administrowanie. Rola giełd nie jest jednak ukształtowana raz na zawsze. Wprowadzono mechanizmy zapewniające dążenie do maksymalizacji efektywności działania samych giełd oraz zapewnienia użyteczności wprowadzanych przez nie instrumentów dla uczestników rynku. Opisane modele RDN i RDB mają zapewniać wzmacnianie nadwyżki rynkowej, czyli ekonomicznego wskaźnika efektu łączenia rynków definiowanego jako suma zysku odbiorców i dostawców wynikająca z udziału w jednym wspólnym rynku. Zysk odbiorców wynika z obniżki ceny zakupu energii w stosunku do ceny, jaką byli gotowi za nią zapłacić. Zysk dostawców wynika $\mathrm{z}$ wyższej ceny sprzedaży energii w stosunku do ceny, za jaką byli gotowi ją sprzedać. Nowy model wewnętrznego rynku energii UE ma generować tego rodzaju bodźce wynikające $\mathrm{z}$ unifikacji architektury rynku, istnienia bodźców do zwiększania efektywności głównych jego uczestników. Wiele kwestii pozostaje jeszcze do przemyślenia i uregulowania, ponieważ na obecnym etapie albo pozostawiono daną kwestię otwartą, albo sposób jej regulacji wymusi podjęcie dalszych działań uszczegóławiających istniejące regulacje.

Pomimo braku przesądzenia tej kwestii, należy przypuszczać, że rolę NEMO będzie pełniła w Polsce Towarowa Giełda Energii S.A. (TGE). Brak jest również przesądzenia, na ile umożliwiona będzie konkurencja dla TGE ze strony NEMO z innych państw członkowskich UE.

Konfiguracja stref cenowych ma również kluczowe znaczenie dla rozwoju rynku hurtowego i inwestycji w wytwarzanie w Polsce. Powoduje ujednolicenie cen pomiędzy tymi strefami i wpływa na wysokość kosztów bilansowania. Ostateczny kształt stref cenowych nie jest jeszcze przesądzony a trwające obecnie prace mają ukształtować optymalny w obecnych warunkach ich kształt. Zasadnym dla rozwoju wewnętrznego rynku energii UE wydaje się budowanie większych stref cenowych w naszym regionie.

\section{LITERATURA}

[1] A Walaszek-Pyzioł, Kilka refleksji na temat europejskich kodeksów sieci (grid codes) [w:] A. Walaszek-Pyzioł (red.), Regulacja - innowacja w sektorze energetycznym, Warszawa 2013, s. 171-179.

[2] ACER, The influence of existing bidding zones on electricity markets, Consultation document, PC_2013_E_04 31, July 2013.

[3] Communication from the Commission, Delivering the internal electricity market and making the most of public intervention, Brussels, 5.11.2013, C(2013) 7243 final.

[4] Dyrektywa 2009/72/WE Parlamentu Europejskiego i Rady z dnia 13 lipca 2009 r., dotycząca wspólnych zasad rynku wewnętrznego energii elektrycznej i uchylająca dyrektywę 2003/54/WE (DzU UE L 221 z 14.08.2009, s. 55). 
[5] Dyrektywa Parlamentu Europejskiego i Rady 2009/73/WE z 13 lipca 2009 r., dotycząca wspólnych zasad rynku wewnętrznego gazu ziemnego i uchylająca dyrektywę 2003/55/WE (DzU UE L 211 z 14.08.2009, s. 94-136).

[6] ENTSO-E Bidding Zone Task Force 21.05.2014, Analytical Framework for Bidding Zone Configurations.

[7] ENTSO-E Market Integration Working Group, Terms of Reference for the early implementation of the NC CACM concerning a Bidding Zone Review in CWE (Belgium, France, Germany, Luxembourg, the Netherlands), DenmarkWest, CEE (Austria, Czech Republic, Germany, Hungary, Poland, Slovenia, Slovakia, Switzerland; and Italy), October 2012.

[8] ENTSO-E, Bidding Zones Review, $1^{\text {st }}$ stakeholder advisory group, Brussels, 27 June 2014.

[9] European Energy Regulation, A Bridge to 2025, Public Consultation Paper, PC_2014_O_01, 29 April 2014.

[10] Rada Europejska, Konkluzje Rady Europejskiej z 4 lutego 2011 r.

[11] Rozporządzenie (WE) nr 713/2009 Parlamentu Europejskiego i Rady z 13 lipca 2009 r., ustanawiające Agencję ds. Współpracy Organów Regulacji Energetyki (DzU UE L 211, 14.08.2009, s. 1).

[12] Rozporządzenie (WE) nr 715/2009 Parlamentu Europejskiego i Rady z 13 lipca 2009 r., w sprawie warunków dostępu do sieci przesyłowych gazu ziemnego i uchylające rozporządzenie (WE) nr 1775/2005 (DzU UE L 211, 14.08.2009, s. 36-54).

THE ROLE OF POWER EXCHANGES IN THE PROCESS OF BUILDING A SINGLE EUROPEAN ELECTRICITY DAY AHEAD AND INTRADAY MARKET

The aim of the article is to analyse the position of energy exchanges in the electricity market of the European Union, which results from the European Commission's draft Regulation establishing a Guideline on Capacity Allocation and Congestion Management. This network code defines the legal regime of the functioning of power exchanges in the coupled Intraday Market (InD) and the Day-Ahead Market (DA) in trade between the European Union bidding zones. Code indicates the proposed model of the wholesale trade, and the institutional framework of its functioning.

Historically, power exchanges were created as a part of the liberalization of national energy markets. Their goal was to build an institutional framework to ensure transparent terms of the transaction, defining a reliable reference price of electricity and providing nondiscriminatory and transparent market information. Currently, they are trading platforms, often with a high level of liquidity, which operate in two areas, i.e. domestic market and cross-border exchange. Ultimately, they serve to build a single EU energy market, highly integrated internally and based on the wholesale market.

The purpose of this article is to identify the proposed new code of network solutions for the functioning of power exchanges Intraday Market and the Day-Ahead Market in trade between the European Union bidding zones.

Keywords: power exchange, NEMO, liberalisation, European Union electricity market, network code, CACM, wholesale market.

DOI:10.7862/rz.2014.hss.70

Przesłano do redakcji: wrzesień 2014

Przyjęto do druku: grudzień 2014 